\title{
TINGKAT KESUKAAN PANELIS TERHADAP BROWNIES KUKUS PADA BERBAGAI FORMULASI TEPUNG AMPAS KELAPA
}

\author{
Masriani $^{1}$, Siti Fatima ${ }^{1}$ \\ ${ }^{1}$ Program Studi Agroteknologi Sekolah Tinggi Ilmu Pertanian Mujahidin Tolitoli \\ Email: masriani901024@gmail.com
}

\begin{abstract}
Coconut pulp as a by-product of cooking oil processing can be further processed into coconut flour which is rich in fiber so that it can be substituted in the processing of various food products. This study aims to find out thelevel of panelists preference for steamed brownies in various coconut pulp flour formulations. This study uses a completely randomized design (CRD), with 5 treatments. Each treatment contained 3 replications so that the total treatment was 15 treatments. Based on the results of the study it can be concluded that the results of organoleptic testing of coconut pulp and 55\%: 50\% flour formulation formulations are still preferred by panelists. The value of the color preference level is (4.82), aroma (4.76), taste (4.87), texture (4.71).
\end{abstract}

Keywords: Coconut pulp flour, steamed brownies

\begin{abstract}
ABSTRAK
Ampas kelapa sebagai hasil samping pengolahan minyak goreng dapat diolah lebih lanjut menjadi tepung kelapa yang kaya kandungan serat sehingga dapat disubtitusi pada pengolahan berbagai produk pangan. Penelitian ini bertujuan untuk mengetahui tingkat kesukaan panelis terhadap brownies kukus pada berbagai formulasi tepung ampas kelapa . Penelitian ini menggunakan Rancangan Acak Lengkap (RAL), dengan 5 perlakuan. Setiap perlakuan diulang sebanyak 3 ulangan sehingga total perlakuan adalah 15 perlakuan. Berdasarkan hasil penelitian dapat disimpulkan bahwa hasil pengujian organoleptik formulasi tepung ampas kelapa dan tepung terigu 55\% : 50\% masih disukai oleh panelis. Nilai tingkat kesukaan warna yaitu (4.82), aroma (4.76), rasa (4.87), tekstur (4.71).
\end{abstract}

Kata kunci: Tepung ampas kelapa, brownies kukus

\section{PENDAHULUAN}

Indonesia merupakan negara yang memiliki lahan tanaman kelapa terbesar di dunia dengan luas sekitar 3.57 juta hektar atau 31 persen dari total lahan kelapa di dunia (Ditjenbun, 2015). Kondisi ini merupakan potensi yang baik bagi Indonesia untuk mengembangkan berbagai produk olahan kelapa. Hal ini juga didukung oleh produksi kelapa Indonesia yang mencapai 18.3 juta ton pada tahun 2016 dan merupakan produsen tertinggi di dunia. Komposisi buah kelapa terdiri dari sabut $33 \%$, tempurung $12 \%$, daging buah $28 \%$, dan air $25 \%$. Seluruh bagian pohon kelapa dapat di manfaatkan untuk kepentingan manusia, sehingga pohon ini sering disebut pohon kehidupan(tree of life).

Seratus buah kelapa akan menghasilkan ampas sebanyak 19,50 kg (Rindengan, dkk., 2004). Berdasarkan data tersebut, jika asumsi buah kelapa memiliki berat $1 \mathrm{~kg}$, maka pengolahan $100 \mathrm{~kg}$ buah kelapa akan menghasilkan ampas kelapa sebesar $19,5 \%$. Besarnya ampas kelapa yang dihasilkan oleh proses pengolahan kelapa secara basah dihadapkan dengan kenyataan bahwa pengolahan ampas kelapa yang masih sangat terbatas.

Pemanfaatan ampas kelapa sampai saat ini masih terbatas untuk pakan ternak dan sebagian dijadikan tempe bonkrek untuk makanan. Sementara itu, ampas kelapa memiliki kandungan serat kasar sekitar 15\% (Putri, 2010). Data tersebut dapat melandasi pengolahan ampas kelapa menjadi tepung ampas kelapa yang memiliki kandungan serat yang tinggi. Ampas kelapa dapat diolah menjadi tepung. Tepung ampas kelapa adalah tepung yang diperoleh dengan cara menghaluskan ampas kelapa yang telah dikeringkan. Tepung ampas kelapa dapat dibuat dari kelapa parut kering yang dikeluarkan sebagian kandungan lemaknya melalui proses pressing. 
Pengolahan tepung ampas kelapa menjadi bahan baku brownies merupakan salah satu alternatif untuk memperluas pemanfaatannya sekaligus meningkatkan nilai tambah. Brownies merupakan produk bakery yang termasuk cake (Cauvain dan Young, 2006). Brownies terbuat dari empat bahan dasar yaitu, tepung, lemak, gula dan telur yang membedakan hanya dengan ditambahkan coklat batang yang dicairkan dan coklat bubuk. Brownies juga termasuk makanan yang sangat disukai dan digemari oleh kalangan anak-anak, dewasa sampai orang tua.

Dengan proses pembuatannya yang relatif mudah.Modifikasi pembuatan brownies dapat dilakukan dengan cara dikukus menggunakan bahan baku tepung ampas kelapa untuk mengurangi proporsi terigu. Berdasarkan hal tersebut dilakukan penelitian penggunaanbahan non terigu seperti tepung ampas kelapa sehingga membantu usaha diversifikasi pangan nasional danmengurangi ketergantungan terhadap bahan pangan impor, khususnyayang berbasis gandum. Penelitian ini bertujuan untuk mengetahui tingkat kesukaan panelis terhadap brownies kukus pada berbagai formulasi tepung ampas kelapa.

\section{METODE}

\section{Lokasi Penelitian}

Penelitian ini telah dilaksanakan pada bulan Februari sampai dengan Maret 2019 , di Laboratorium Ilmu-ilmu Pertanian Sekolah Tinggi Ilmu Pertanian (STIP) Mujahidin Tolitoli di Kelurahan Tuweley Kecamatan Baolan Kabupaten Tolitoli Provinsi Sulawesi Tengah.

\section{Bahan Dan Alat Penelitian}

Bahan yang digunakan dalam pembuatan tepung ampas kelapa dan brownies antara lain :ampas kelapa, tepung ampas kelapa, minyak kelapa, telur, tepung terigu, dark chocolate, coklat bubuk, gula pasir, elmusifier, susu kental manis coklat.

Alat yang digunakan dalam pembuatan brownies adalah oven listrik, mixer, talenan, pisau, panic kecil, cetakan,alat steaming, parut coklat, ayakan, spatula,loyang, kertas label,alat tulis menulis dan kamera. Peralatan kimia yang digunakan untuk analisis adalah timbangan analitik, alumunium foil, gelas ukur, stopwatch, thermometer.

\section{Metode Penelitian}

Penelitian ini menggunakan Rancangan Acak Lengkap dengan perlakuan formulasi tepung ampas kelapa sebagai berikut:

nk1 : 0\% (tepung ampas kelapa) dan 100\% (tepung terigu)

nk2 : $\quad 25 \%$ (tepung ampas kelapa) dan $75 \%$ (tepung terigu)

nk3 : $\quad 50 \%$ (tepung ampas kelapa) dan $50 \%$ (tepung terigu)

nk4 : $\quad 75 \%$ (tepung ampas kelapa) dan $25 \%$ (tepung terigu)

nk5 : $\quad 100 \%$ (tepung ampas kelapa) dan $0 \%$ (tepung terigu)

Setiap perlakuan terdapat 3 kali ulangan sehingga total perlakuan sebanyak 15 perlakuan. Model matematis untuk rancangan acak lengkap (Gaspersz, 1991) adalah sebagai berikut :

Yij $=\mu+A i+\epsilon i j$

$\mathrm{i}=1,2,3, \ldots \ldots \ldots \ldots, \mathrm{a} \quad \mathrm{j}=1,2,3 \ldots \ldots \ldots \ldots, \mathrm{u}$

Yijk : Pengamatan Faktor Utama taraf ke$\mathrm{i}$, Ulangan ke-j dan

Faktor Tambahan taraf ke-k

$\mu \quad$ : Rataan Umum

Ai : Pengaruh Utama pada taraf ke-i

cij : Pengaruh Galat I pada Faktor Utama ke-i dan Ulangan ke-j

eijk : Pengaruh galat II pada Faktor Utama taraf ke-i, Ulangan

ke-j dan faktor tambanan pada taraf ke-k Analisa data dilakukan dengan menggunakan sidik ragam. Jika hasilnya menunjukkan berpengaruh nyata maka dilanjutkan dengan uji lanjut BNT taraf 5\%.

\section{Proses Pembauatan Tepung Ampas Kelapa}

Proses pembuatan tepung kelapa dari ampas kelapa adalah sebagai berikut ampas kelapa dicuci untuk mengeluarkan kotoran-kotoran yang terdapat pada ampas kelapa.Arnpas kelapa dimasukkan ke dalarn tempat perendaman berisi air suhu $70^{\circ} \mathrm{C}$ selama 10 menit. Ampaskelapa ditiriskan untuk mengurangi kadar air sebelum dikeringkan. Setelah itu dilakukan pengeringan. Pengeringan dilakukan menggunakan oven pada suhu $70^{\circ} \mathrm{C}$ selama 24 jam. Kemudian dilakukan penggilingan. Penggilingan dilakukan untuk mendapatkan butiran-butiran. Proses ini pentinguntuk menentukan ukuran tepung kelapa.Tepung kelapa diayak dengan ayakan.

\section{Proses Pembuatan Brownies Kukus}

Proses pembuatan brownies sebagai berikut lelehkan coklat batang (dark chocolate) dan tambahkan minyak kemudian didinginkan. Kocok telur ayam dan gula pasir hingga mengembang, kemudian campur tepung sesuai perlakuan dan coklat bubuk. Aduk hingga rata. 
Masukkan lelehan coklat ke adonan dan kembali diaduk hingga rata. Tuang adonan ke dalam cetakan dan kukus adonan selama 30 menit. Brownies kukus siap disajikan.

Tabel 1. Formulasi Tepung pada Pembuatan Brownies Kukus

\begin{tabular}{|c|c|c|c|c|c|}
\hline \multirow{2}{*}{ Bahan } & \multicolumn{5}{|c|}{ Perlakuan } \\
\hline & $\mathrm{nk}_{1}$ & $\mathrm{nk}_{2}$ & $\mathrm{nk}_{3}$ & $\mathrm{nk}_{4}$ & $\mathrm{nk}_{5}$ \\
\hline Tepung ampas kelapa (g) & 0 & 31,25 & 62,5 & 93,75 & 125 \\
\hline Tepung terigu $(\mathrm{g})$ & 125 & 93,75 & 62,5 & 31,25 & 0 \\
\hline Dark chocolate $(\mathrm{g})$ & 100 & 100 & 100 & 100 & 100 \\
\hline Telur (butir) & 6 & 6 & 6 & 6 & 6 \\
\hline Coklat bubuk (g) & 50 & 50 & 50 & 50 & 50 \\
\hline Minyak (ml) & 75 & 75 & 75 & 75 & 75 \\
\hline Gula pasir (g) & 225 & 225 & 225 & 225 & 225 \\
\hline Emulsifier (g) & 5 & 5 & 5 & 5 & 5 \\
\hline Susu coklat $(\mathrm{g})$ & 75 & 75 & 75 & 75 & 75 \\
\hline
\end{tabular}

\section{Parameter Penelitian}

Kadar air (AOAC, 1990)

Penentuan total padatan dihitung dengan mengunakan metode kadar air. Adapun prosedur analisa kadar air dilakukan dengan cara : cawan dikeringkan dalam oven pada suhu 105 oC selama 30 menit dan didinginkan dalam desikator selama 20 menit.Sebanyak $3 \mathrm{~g}$ sampel ditimbang dengan cepat ke dalam cawan kering, cawan yang berisi sampel dikeringkan dalam oven dengan suhu $105 \mathrm{oC}$ selama 6 jam. Berat sampel ditimbang hingga konstan. Berat sampel dikatakan konstan apabila selisih penimbangan tidak melebihi 0,2 mg. Kadar air dalam bahan dihitung dengan menggunakan persentase basis basah, dengan rumus perhitungan :

$$
\% \text { kadar air }=\frac{b-(c-a)}{b} \times 100 \%
$$

Dimana: $\quad \mathrm{a}=$ berat cawan kering yang sudah konstan

$$
\begin{aligned}
& \mathrm{b}=\text { berat sampel awal } \\
& \mathrm{c}=\text { berat cawan dan sampel kering }
\end{aligned}
$$
yang sudah konstan

\section{Uji Sensori}

Pada penelitian ini dilakukan uji sensori dengan menggunakan metode uji hedonik. Panelis yang digunakan adalah panelis tidak terlatih sebanyak 31 orang. Penilaian yang diberikan pada penelitian ini meliputi tingkat kesukaan terhadap warna, aroma, rasa, dan tekstur. Panelis yang digunakan merupakan panelis dengan kisaran usia dari 18 tahun sampai dengan 30 tahun. Uji sensori dilakukan terhadap warna berdasarkan tingkat kesukaan konsumendengan skala hedonik. Uji yang diamati adalah warna, aroma,rasa, dan tekstur. Kriteria penilaiandikonversikan dalam angka
Adapun formulasi tepung ampas kelapa adalah sebagai berikut, yaitu (7) sangat suka, (6) suka, (5) agak suka, (4)agak tidak suka, (3) tidak suka, (2) sangat tidak suka, dan (1) amat sangat tidak suka.

\section{Warna}

Komponen yang sangat penting dalam menentukan kualitas dan derajat penerimaan pada suatu bahan pangan yaitu warna. Suatu bahan pangan yang dinilai enak dan teksturnya baik tidak akan dimakan apabila memiliki warna yang kurang sedap dipandang atau telah menyimpang dari warna yang seharusnya. Penilaian secara subjektif paling mudah dan paling berkesan yang dilakukan oleh indera penglihatan yang berhubungan dengan warna

\section{Aroma}

Pengujian terhadap sifat organoleptik aroma produk bertujuan untuk memperkirakan penerimaan konsumen terhadap produk. Penilaian yang dilakukan dengan menggunakan indera penciuman, misalnya bau busuk atau bau harum pada makanan biasa disebut dengan pencicipan jarak jauh.

\section{Rasa}

Rasa merupakan bagian yang sangat penting pada suatu produk dalam penerimaan oleh konsumen. Penialaian yang dilakukan melalui indra pencicip, dibedakan menjadi empat cicip rasa, yaitu manis, pahit, asin, dan asam.

\section{Tekstur}

Tekstur merupakan bagian yang sangat penting pada suatu produk dalam penerimaan oleh konsumen. Penilaian melalui perabaan atau sentuhan, memilki peranan penting dalam penerimaan makanan didalam mulut atau perabaan dengan jari. 


\section{HASIL DAN PEMBAHASAN}

\section{Warna}

Hasil uji organoleptik (Tingkat kesukaan panelis) terhadap warna brownies kukus ampas kelapa disajikan pada lampiran tabel 1a, sedangkan sidik ragamnyadisajikanpada tabellb. Hasil sidik ragam, menunjukkan bahwa perlakuan formulasi tepung ampas kelapa berpengaruh sangat nyata terhadap warna brownies kukus. Pada tingkat kesukaan panelis terhadap warna brownies kukus bedasarkan uji organoleptik disajikan pada gambar 1.

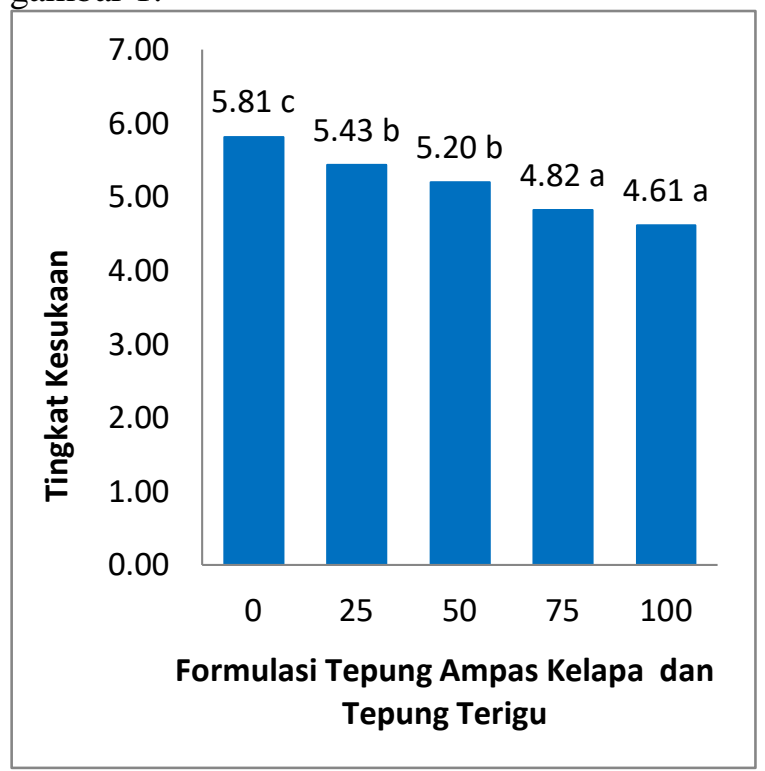

Gambar 1. Tingkat Kesukaan Panelis Terhadap Warna Brownies Kukus Dengan Penambahan Tepung Ampas Kelapa

Berdasarkan hasil uji BNT $5 \% \quad(0,32)$ menunjukan bahwa warna untuk semua perlakuan 50\% ampas kelapa agak disukai oleh panelis, nilai tingkat kesukaan panelis terhadap warna brownies kukus yaitu berkisar antara 5.20-5.81 (agak disukai).

Warna merupakan daya tarik suatu produk sebelum konsumen mengenal produk makanan dan atribut lainnya (Asmaraningtyas 2014). Tingkat kesukaan panelis pada atribut warna berpengaruh tidak nyata, hasil skala nilai tertinggi yaitu 5.81. Warna juga merupakan parameter yang terhadap produk, panelis akan menyukaiproduk jika dilihat dari warnanya yang tidak menyimpang dari warna yang seharusnya.

\section{Aroma}

Hasil uji organoleptik (tingkat kesukaan panelis) terhadap aroma brownies kukus ampas kelapa disajikan pada lampiran tabel 2a, sedangkan sidik ragamnya disajikan pada tabel b. Hasil sidik ragam, menunjukkan bahwa perlakuan formulasi tepung ampas kelapa berpengaruhnyata terhadap aroma brownies kukus. Pada tingkat kesukaan panelis terhadap aroma brownies kukus bedasarkan uji organoleptik disajikan pada gambar 2 .

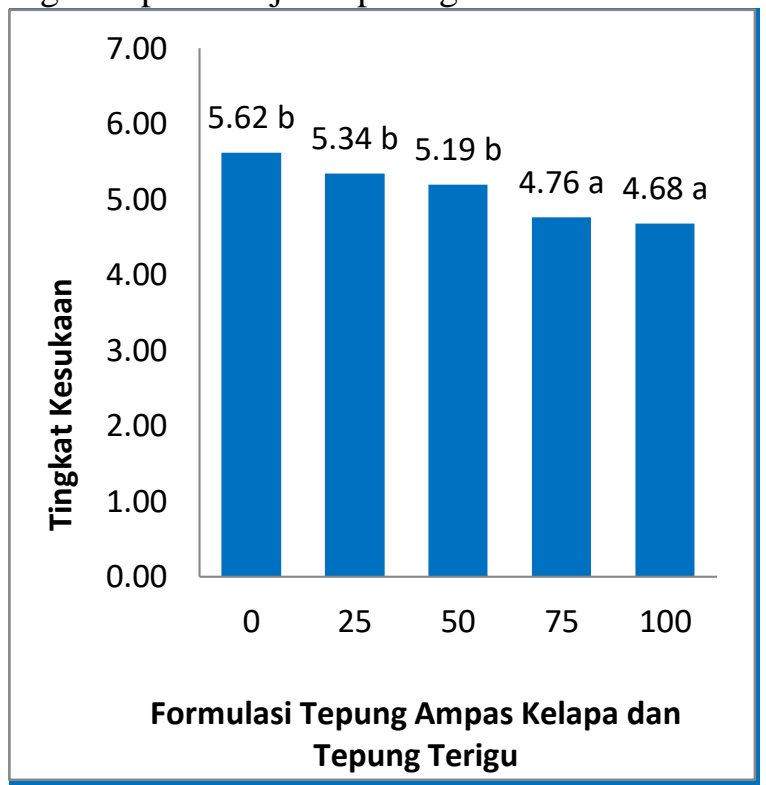

Gambar 2. Tingkat Kesukaan Panelis Terhadap Aroma Brownies Kukus Dengan Penambahan Tepung Ampas Kelapa

Berdasarkan hasil uji BNT $5 \% \quad(0.42)$ menunjukan bahwa perlakuan $100 \%$ berbeda nyata dengan perlakuan $0 \%, 25 \% 50 \%$, akan tetapi berbeda tidak nyata dengan perlakuan 75\%. Nilai tingkat kesukaan panelis terhadap aroma brownies kukus berkisar antara 5,34-1,62 (disukai) seperti telihat pada gambar 2.

Aroma dapat dijadikan indicator untuk menentukan terjadinya kerusakan pada produk (pradipta 2011). Penambahan tepung ampas kelapa yang semakin banyak, akan membuat tingkat kesukaan panelis terhadap parameter aroma menurun. Hal ini karena aroma dari ampas kelapa yang khas, tetapi aroma dariampas kelapa dapat menurun karena sebelum melakukan proses pengeringan dilakukan proses blaching selama 10 menit. Atribut aroma merupakan atribut yang sangat penting karena jika aroma produk sudah menyimpang seperti tengik yang berasal dari ampas kelapa, maka produk sudah tidak baik lagi. Hal ini dapat dikatakan aroma juga dapat digunakan sebagai parameter untuk simpan produk.

\section{Rasa}

Hasil uji organoleptik (Tingkat kesukaan panelis) terhadap rasa brownies kukus ampas 
kelapa disajikan pada lampiran tabel 3a, sedangkan sidik ragamnya disajikan pada tabel 3b. Hasil sidik ragam, menunjukkan bahwa perlakuan formulasi tepung ampas kelapa berpengaruh tidak nyata terhadap warna brownies kukus. Pada tingkat kesukaan panelis terhadap warna brownies kukus bedasarkan uji organoleptik disajikan pada gambar 3.

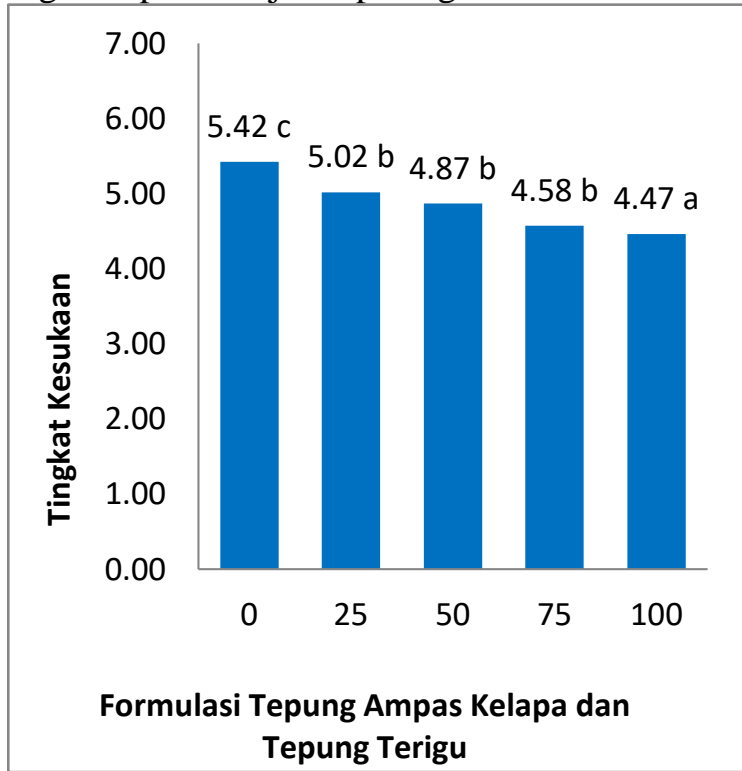

Gambar 3. Tingkat Kesukaan Panelis Terhadap Rasa Brownies Kukus Dengan Penambahan Tepung Ampas Kelapa dan Tepung Terigu

Berdasarkan hasil uji BNT 5\% $(0,50)$ menunjukan bahwa warna untuk semua perlakuan disukai oleh panelis, nilai tingkat kesukaan panelis terhadap rasa brownies kukus yaitu berkisar antara 5.025.42 (agak disukai). Rasa merupakan faktor terpenting dalam menentukan keputusan konsumen untuk menerima produk atau tidak (Purwadi 2017). Penambahan tepunga mpas kelapa pada setiap formulasi dapat mempengaruhi kesukaan panelis pada brownies, semakin banyakt epung ampas kelapa maka semakin menurun tingkat kesukaan panelis terhadap produk.

\section{Tekstur}

Hasil uji organoleptik (tingkat kesukaan panelis) terhadap teksturbrownies kukus ampas kelapa disajikan pada lampiran tabel 4a, sedangkan sidik ragamnya disajikan pada tabel 4b. Hasil sidik ragam, menunjukkan bahwa perlakuan formulasi tepung ampas kelapa berpengaruh sangat nyata terhadap tekstur brownies kukus.
Pada tingkat kesukaan panelis terhadaptekstur brownies kukus bedasarkan uji organoleptik disajikan pada gambar 4 .

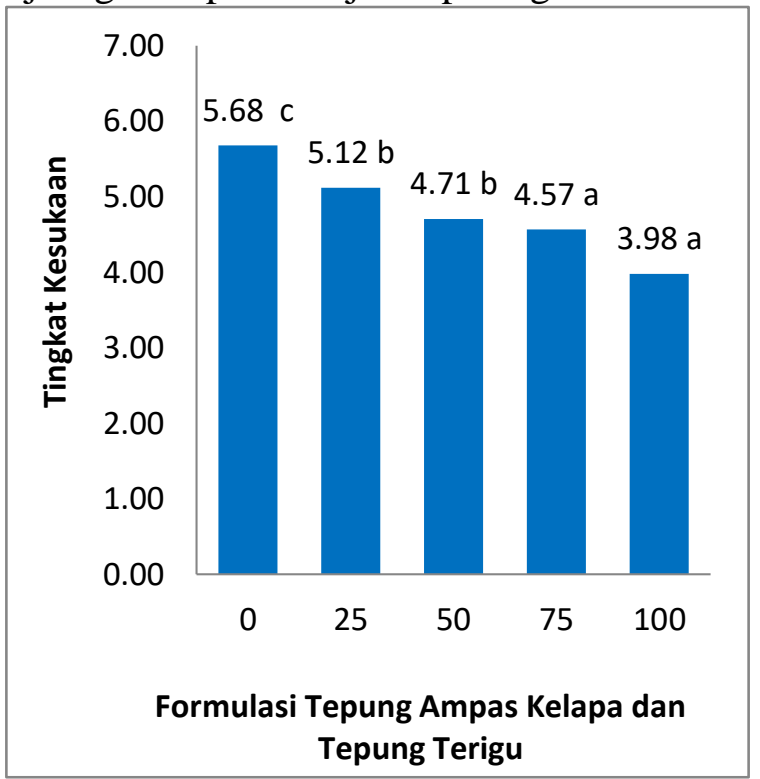

Gambar 4. Tingkat Kesukaan Panelis Terhadap Tekstur Brownies Kukus Dengan Penambahan Tepung Ampas Kelapa

Berdasarkan hasil uji BNT 5\% (0.35) menunjukan bahwa perlakuan $100 \%$ berbeda sangat nyata dengan perlakuan $75 \%, 50 \%, 50 \% 25 \%$ tepung ampas kelapa dan tepung terigu, akan tetapi berbeda tidak nyata dengan perlakuan $0 \%$ tepung ampas kelapa, nilai tingkat kesukaan panelis terhadap tekstur brownies kukusyaitu 5.68 (agak disukai). Tekstur merupakan cirri dari suatu bahan yang dapat dirasakan oleh indera peraba, perasa dan indra penglihatan (Midayanto dan Yuwono 2014).

\section{KESIMPULAN}

Hasil pengujian organoleptik formulasi tepung ampas kelapa dan tepung terigu $55 \%: 50 \%$ masih disukai oleh panelis. Nilai tingkat kesukaan warna yaitu (4.82), aroma (4.76), rasa (4.87), tekstur (4.71).

\section{UCAPAN TERIMA KASIH}

Terima kasih penuliskan ucapkan kepada Dr. Ir. Eko Hary Pudjiwati, MP., Dr. Amarullah, S.P., MP., Kartina, S.Pd., M.Sc., dan Aditya Murtilaksono, S.Si., MP. yang telah banyak memberikan kritik dan saran dalam pembuatan skripsi ini. 


\section{DAFTAR PUSTAKA}

AOAC (Association of Official Agricultural Chemist). 1990. Official Methods of Analysis. Washington DC, USA.

Asmaraningtyas D. 2014. Kekerasan, Warna dan Daya Tarik Biskuit yang Disubsitusi Tepung Labu Kuning [Skripsi]. Surakarta (ID): Universitas Muhammadiyah Surakarta.

Direktorat Jendral Perkebunan, 2015. Statistik Perkebunan Indonesia 2014-2016. Kelapa. Jakarta (Id): Ditjenbun

Gauvain, S. P., dan Young L.S.Y. 2006. Baked Products : Science, Technology and Practice. Blackwell Publishing Ltd. Garsington Road.

Gaspersz, V. 1991. Metode Perancangan Percobaan. CV.ARMICO

Midayanto Dan Yuwono S. 2014. Penentuan Atribut Mutu Tekstur Tahu untuk Direkomendasikan sebagai Syarat Tambahan dalam Standar Nasional Indonesia. Jurnal Pangan dan Agroindustri. 2(4): 259-267.

Pradipta I. 2011. Karasteristik Sifat Fisikokimia dan Sensori Snack Bar Tempe dengan Penambahan Salak Pohon Kering [skripsi]. Surakarta (ID): Universitas Sebelas Maret.

Putri, Meddiati Fajri. 2014. Kandungan Gizi dan Sifat Fisik Tepung Ampas Kelapa Sebagai Bahan Pangan Sumber Serat. J. Teknubuga 2 (2): 32-43.

Purwadi DCAH. 2017. Analisis Sifat Fisik, Organoleptik dan Total Plate Count pada Crakers dengan Fortifikasi Tepung Tempe dan Kolesom [skripsi]. Jakarta (ID): UniversitasTriologi

Rindengan, B. 2013. Laporan Hasil Penelitian. Proses pengolahan biskuit kaya serat dan asam lemak rantai medium menggunakan tepung ampas kelapa. 